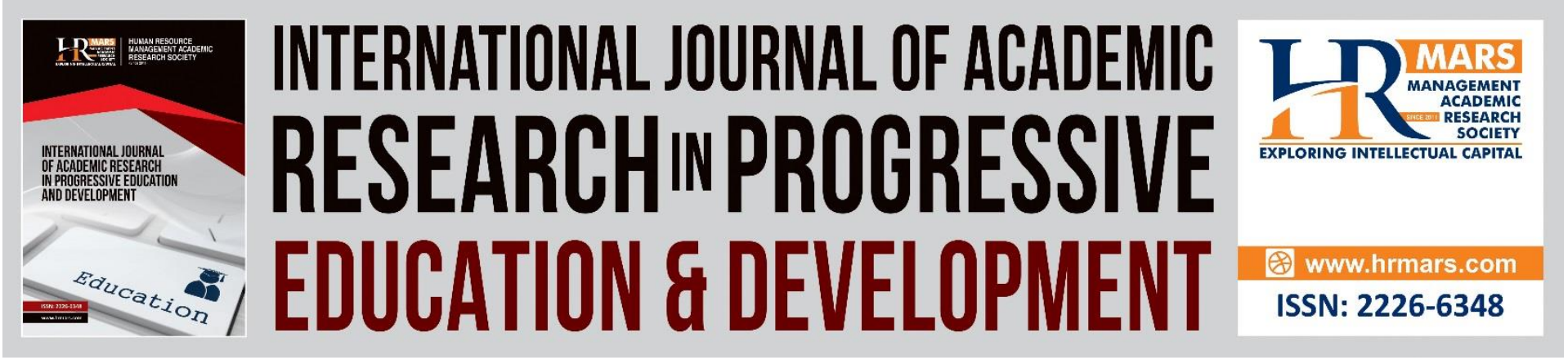

\title{
Social Media Addiction as Correlates of Academic Procrastination and Achievement among Undergraduates of Nnamdi Azikiwe University Awka, Nigeria
}

Elizabeth Ifeoma Anierobi, Chukwuemeka E. Etodike, Nkechi Uzochukwu Okeke \& Anthony Obinna Ezennaka

To Link this Article: http://dx.doi.org/10.6007/IJARPED/v10-i3/10709

DOI:10.6007/IJARPED/v10-i3/10709

Received: 04 June 2021, Revised: 08 July 2021, Accepted: 27 July 2021

Published Online: 12 August 2021

In-Text Citation: (Anierobi et al., 2021)

To Cite this Article: Anierobi, E. I., Etodike, C. E., Okeke, N. U., \& Ezennaka, A. O. (2021). Social Media Addiction as Correlates of Academic Procrastination and Achievement among Undergraduates of Nnamdi Azikiwe University Awka, Nigeria. International Journal of Academic Research in Progressive Education and Development, 10(3), 20-33.

Copyright: (C) 2021 The Author(s)

Published by Human Resource Management Academic Research Society (www.hrmars.com)

This article is published under the Creative Commons Attribution (CC BY 4.0) license. Anyone may reproduce, distribute, translate and create derivative works of this article (for both commercial and non-commercial purposes), subject to full attribution to the original publication and authors. The full terms of this license may be seen at: http://creativecommons.org/licences/by/4.0/legalcode

Vol. 10(3) 2021, Pg. 20 - 33

Full Terms \& Conditions of access and use can be found at http://hrmars.com/index.php/pages/detail/publication-ethics 


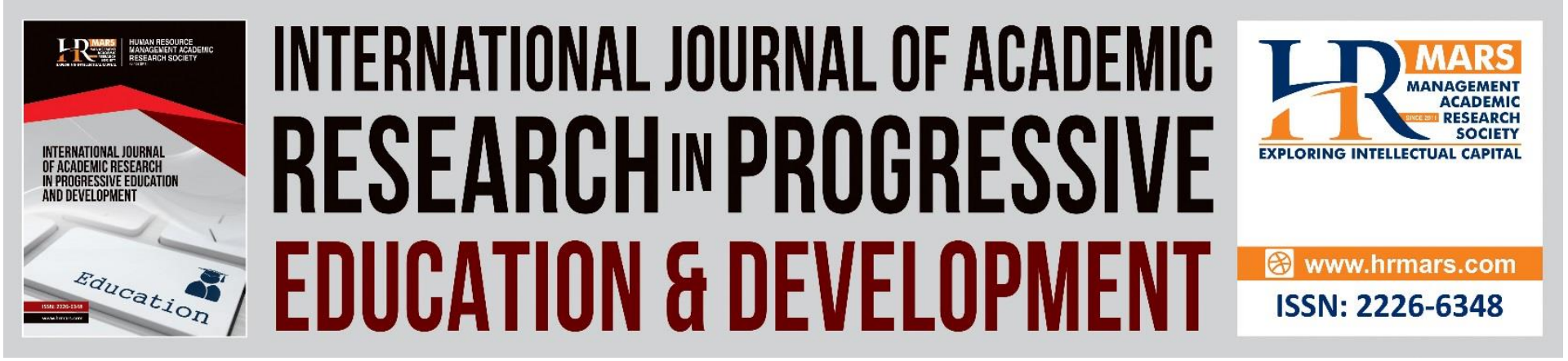

\title{
Social Media Addiction as Correlates of Academic Procrastination and Achievement among Undergraduates of Nnamdi Azikiwe University Awka, Nigeria
}

\author{
${ }^{1}$ Elizabeth Ifeoma Anierobi, ${ }^{2}$ Chukwuemeka E. Etodike, ${ }^{1}$ Nkechi \\ Uzochukwu Okeke \& ${ }^{1}$ Anthony Obinna Ezennaka \\ ${ }^{1}$ Department of Educational Foundations, Nnamdi Azikiwe University, Awka, ${ }^{2}$ Department of \\ Psychology, Nnamdi Azikiwe University, Awka
}

\begin{abstract}
Youths' inquisitiveness draws and attracts them to innovations; social media is not different. Among undergraduates, the use of social media as an evolving way of life may have reached addiction level with its consequences. Given this disturbing situation, this study explored compulsive social media use as an encouraging factor in academic procrastination among students with its consequences on students' academic achievement among undergraduate of Nnamdi Azikiwe University. Using a correlation design which was tested at 0.05 significance, the study evaluated the responses of 965 undergraduate students selected through cluster sampling during their examinations. Social Media Scale (SSMAS) and Academic Procrastination Scale (APS) was used as instrument for data collection. Academic achievement was measured using the students' cumulative grade point. Data were analyzed using regression analysis and result revealed that $33.47 \%$ of the undergraduate exhibit high levels of academic procrastination, $42.70 \%$ exhibit a moderate level of academic procrastination $23.83 \%$ exhibit academic procrastination among undergraduate students. The result further indicated that social media addiction predicted both academic procrastination and academic achievement among the undergraduates. Based on the findings of the study, it was recommended among others, that students should be channeled into the proper use of social media for academic purposes irrespective of their gender with counseling services to help those with chronic or addictive use.
\end{abstract}

Keywords: Social Media Addiction, Gender, Academic Procrastination, Academic Achievement

Introduction

One of the primary reasons for getting enrolled in any university academic programme is to acquire advanced knowledge for better academic achievement to prepare the students to fit into the global trend where education is an essential development index. University academic programmes expose students to rigorous academic tasks which require an utmost 
commitment by students to achieve desired academic results (Ahmed et al., 2017). To get students committed to their studies and academic activities, teachers assign academic tasks to them to get them explore ideas and knowledge which are meant to prepare them for academic success (Anierobi \& Unachukwu, 2020). Tasks mostly assigned to students include take-home assignments, projects, self-discovery tasks and majority of information could be accessed through the internet because this is the information and technology era.

However, it is a common observation to students so occupied with social media to the detriment of their academic responsibilities. Not minding the negative antecedents of social media on youths (Etodike \& Orjiakor, 2018) such as exposure and vulnerability to sexual promiscuity, crime and bad influence, this could be labeled a misplaced priority in time management needed for the prompt attention to their academic tasks. For example, the pleasures of social media can cause a delay in students' academic tasks which if not managed may lead to academic procrastination.

Academic procrastination can thwart a student's academic set goals when they fail to order their priorities aright. Karima et al. (2017) counseled that students should always prioritize their use of time properly to enable them to undertake their academic tasks as appropriate without unnecessary delays. Nevertheless, most students seem to procrastinate and postpone attending to their academic tasks at will. Usually, students are abated by their peers in procrastination behaviour except if such students are assertive or given assertiveness training (Etodike et al., 2017). Academic procrastination implies unnecessarily postponing carrying out or completing an academic task by students. This implies that academic procrastination occurs when students give their attention to other activities at the expense of their academic responsibilities. For instance, academic procrastination results when students are caught in the web of many addictive behaviours and became distracted from paying due attention to carrying out their academic tasks when necessary. Ipem and OkwaraKalu (2020) asserted that students spend more time on social communication which distracts them from actively engaging in their academic activities.

Similarly, Hartney (2019); Tayo et al. (2019) averred that addictive and anti-social behaviours of such as internet fraud through online networking, gambling and video games have shifted the attention of students from their studies. Considering that students have challenges managing their time most effectively (Etodike et al., 2020), there is no way a student who lacked engagement in their studies could not be friends with academic procrastination. There are attendant paradoxes of procrastination behaviour as it brings about fear, laziness, loss of interest and anxiety over uncompleted tasks which are perpetually postponed. In the views of the researchers, these issues may adversely rest on students' academic achievement which is their primarily and the most important aim of attending school.

\section{Review of Literature}

\section{Academic Procrastination}

Procrastination has been with man from time immemorial. Individuals sometimes postpone attending to a function, task or responsibility to pay attention to another thing of priority to them. Some people get involved in the desired task but one thing or the other kept distracting them from timely accomplishing the task. Others on the other hand might keep postponing that they may never at all embark on a wishful project or task. Procrastination is, therefore, one of the major factors behind one's inability to timely complete or carries out a 
task (He, 2017). Procrastination no doubt cuts across all human endeavours including in academic affairs.

Academic procrastination could result from fear of failure, lack of motivation lackadaisical attitude or feeling of confidence in one's ability to perform the academic task (Okoiye \& Nlemadim, 2017). No wonder, Oriol et al (2016) lamented that teachers are daily faced with the challenge of getting students actively engaged to ensure promptness in both carrying out academic roles and possible prompt graduation. This is because academically engaged students fully concentrate and are enthusiastic about learning (Alrashidi et al., 2016). This virtue could be an antidote to procrastinating over carrying out or delaying completion of their academic tasks irrespective of the student's gender. Nevertheless, students get distracted from academic tasks most often which make them either postpone tackling the task or delay in its completion. Distractions could result from negative influences of additive behaviours of students and an example of such behaviours is social media addiction.

\section{Compulsive Social Media Use}

The use of mobile phones typically android version berthed the proliferation of social media with all its attendant problems. Social media addiction or compulsive social media use has been termed a global problematic issue of concern and was observed to be more prevalent among students (Ndubuaku et al., 2020, Yakut \& Kuru, 2020). Social media in itself is not bad per se because it has its pros. This is because social media handles provide userfriendly platforms for easy dissemination of information among the users. Okeke and Anierobi (2020) averred that social media affords students with a speedy and effective avenue of exchanging information in areas of education. This when properly utilized could have a positive impact on the education of students. For instance, a study (Sandeep et al. 2019) on the impact of social media on academic performance and interpersonal relations among students in a tertiary institution in India revealed that social media has a positive impact on their academic performance and social well-being. Compulsive social media use has also many indirect effects such as online sexual harassment (Anierobi et al., 2021) in campus which mostly affects the female students which is caused by online nudity and exposure in the campus have both direct and indirect influence on student academic life.

Studies revealed that social media addiction has impacts on students in many aspects of their lives and endeavours. For instance, a study by Oumaima et al. (2020) found that social media addiction has negative impacts on studies, health, relationship and general well-being of Moroccan university students. In line with this finding, Tateno et al (2020) and Haand and Shuwang (2020) observed that addiction to social media could lead to poor feeding habit, sleepless nights, brain drain, depression and academic failure. This could be as a resultant distraction and the gluing power over the students who became a victim of addiction to social media. Social media addiction could expose students to different harmful sites to their cognitive and social development. Researchers revealed that constant exposure to violent social media handles promotes aggressive and deviant behaviours among students (Odofin \& Ofojebe, 2020; Okeke \& Joe-Akunne, 2020). Likewise, social media addiction could impact on academic behaviour of students.

\section{Academic Achievement}

Academic achievement is defined according to how well a student performs over time in tests and examinations in the school setting. It is also the measure of students learning 
outcome (Ikwuka et al., 2020). These tests and examinations may be teacher-made tests and/or standardized tests. Hence, research contends that academic achievement as determination of the degrees of attainment of the individual students in tasks, courses and programmes to which the individual student have been sufficiently exposed and measured using civic achievement test. Studies (e.g. Anierobi et al. 2021, Albarashdi, 2020, Ipem \& Okwara-Kalu, 2020) have revealed that social media addiction has a high and positive relationship with the academic performance of students On the other hand, Uztermur (2020) in his study found that social media addiction has a positive relationship with academic procrastination but a negative relationship with academic performance. Similarly, Nwosu et al. (2020), in their study found that internet addiction predicted academic procrastination among undergraduate students. Hayat et al (2020) equally found that internet addiction has a positive and significant correlation with academic procrastination of medical students in Shiraz University with male students more addicted to the internet than female students. Hayat et al (2020) also found that male students were more addicted to the internet than female students.

In another study, Chen (2019) found that female students were more addicted to social networking addiction than their male counterparts. On the other hand, Hou et al. (2019) found a negative association between social addiction and academic performance of undergraduate students of Peking, University, China. In their study, Yakut and Kuru (2020) found that social media addiction has no direct positive effect on academic procrastination among students. Nevertheless, Ipem and Okwara-Kalu noted that the majority of the students have internet-friendly phones and they usually source for information online. Ipem and Okwara-Kalu further aver that though most students visit the internet for useful information for academic tasks but end up distracted in WhatsApp, Facebook and the likes. This distraction which could lead to academic procrastination is usually experienced by most students irrespective of gender.

Previous studies, however, are inconsistent on whether gender is a significant factor in promoting academic procrastination among students. For instance, Balkins and Duru (2017), in their study with university students found that gender has a relationship with academic procrastination and those male students had a high level of academic procrastination than their female counterparts. Balkins and Duru further found that academic procrastination was negatively related to academic performance among the students. Other studies found a significant difference in academic procrastination among male and female college students implying that gender has a positive relationship with academic procrastination (Gohil, 2014; Vij, 2016). On the other hand, Mahasneh et al (2016) and Ajayi (2020) found no significant difference in academic procrastination among male and female undergraduate students implying that gender has a negative relationship with academic procrastination.

Similarly, previous studies were not consistent on the relationship between gender and academic achievement of students. For instance, some studies with secondary school students found that gender has no significant relationship with academic achievement (Anierobi, 2019; Odofin, 2020; Unachukwu, et al., 2020). On the other hand, other researchers found that gender has a significant relationship with the academic achievement of students (Baji, 2020; Mwihia, 2020; Sumaila \& Bello, 2018)

Though literature is agog with the negative impacts of social media addiction on health, relationship and academic performance, it is inconsistent with the association of social 
media addiction with academic procrastination and academic achievement of students. This study, therefore, sought to find out if the relationship of social media addiction with academic procrastination and achievement among undergraduate students of Nnamdi Azikiwe University, Awka using a correlation method will be consistent with either of the results in the existing literature.

\section{Research Question}

To give direction to this study, the following research questions and hypotheses were posed:

- What is the level of academic procrastination among undergraduate students of NAU, Awka?

- What is the relationship between social media addiction and academic procrastination among undergraduate students of NAU, Awka?

- What is the relationship between social media addiction and academic achievement among undergraduate students of NAU, Awka?

- What is the relationship between gender and academic procrastination among undergraduate students of NAU, Awka?

- What is the relationship between gender and academic achievement among undergraduate students of NAU, Awka?

- There is no significant relationship between social media addiction and academic procrastination among undergraduate students of NAU, Awka.

- There is no significant relationship between social media addiction and academic achievement among undergraduate students of NAU, Awka

\section{Method}

The study adopted a correlation research design. The population of the study consisted of all the 200 level to 400 level undergraduate students of the Faculty of Social Sciences, Nnamdi Azikiwe University totaling 3,142. The sample of the study was drawn from the population using a simple convenient sampling method. Out of the 5 Departments in the Faculty, 193 students were proportionally picked at random from each Department cutting across all levels. Through proper explanation of the purpose of the study, their consent was got and the participants selected, easily filled out the questionnaires. A total of 965 undergraduate students selected formed the sample size for the study. The 100 level students were excluded because their actual number was not available at the time of the study as many of them could not resume for the fear of the environmental hazards (Etodike et al., 2021) due to COVID-19 pandemic. The few of them that resumed were still processing their documentation as they were affected by school shutdown due to the global Covid-19 pandemic.

Two sets of instruments were used in eliciting information from the participants. Social media addiction was measured using the Social Media Addiction Scale (SMAS) adapted from Ipem and Okwara-Kalu (2020). This is a 4-point Likert type scale that consists of 20 items designed to identify individuals who are mildly, moderately and highly addicted to social media. All the items are positive; therefore, the higher scores indicate that the student perceives himself as highly susceptible to social media addiction. The instrument was modified into a 4-point Likert response scale of strongly agree (4), agree (3), disagree (2) and strongly disagree (1). 
DEVELOPMENT

Vol. 10, No. 3, 2021, E-ISSN: 2226-6348 @ 2021 HRMARS

Academic Procrastination Scale (APS) was adapted from McCloskey and Scieloz (2015). It is a 25-item 5-point Likert scale, modified into a 4-point Likert response scale of strongly agree (4), agree (3), disagree (2) and strongly disagree (1). Items that are negatively worded $(1,8,12,14 \& 20)$ were reversed during scoring. Cronbach Alpha was used in determining the reliability of the two instruments which yielded a coefficient alpha of 0.70 and 0.72 for SSMAS and APS respectively.

Data on the academic performance of the students were obtained from the undergraduate students' 2018/2019 academic session Cumulative Grade Point (CGP). A column was provided under the Bio Data where the respondents indicated both their gender and their CGP. Data collected were analyzed Frequency, Percentages, Pearson Product Moment Correlation for answering research questions and linear regression was applied in testing the hypothesis.

\section{Results}

Table 1: Frequency and percentage of the level of academic procrastination among undergraduate students

\begin{tabular}{lll}
\hline Levels of Academic Procrastination & Frequency & Percentage \\
\hline High & 323 & $33.47 \%$ \\
Moderate & 412 & $42.70 \%$ \\
Low & 230 & $23.83 \%$ \\
Total & 965 & $100 \%$ \\
\hline
\end{tabular}

Data in Table 1 revealed that 323 numbers representing $33.47 \%$ of the undergraduate students in NAU exhibit a high level of academic procrastination, 412 representing $42.70 \%$ exhibit moderate level of academic procrastination while 230 representing $23.83 \%$ exhibit academic procrastination among undergraduate students.

Table 2: Simple correlation analysis of the relationship between compulsive social media use and academic procrastination among undergraduate students

\begin{tabular}{llcc}
\hline$r$ & r square & $r$ square adjusted & Std. Error of the Estimate \\
\hline 0.959 & 0.920 & 0.919 & 2.40883 \\
\hline
\end{tabular}

Data in Table 1 reveals that the correlation coefficient between compulsive social media use and academic procrastination is $r=0.959$ with a coefficient of determination of 0.920 accounting for $9.2 \%$ in the relationship. This shows that there is a high and positive relationship between compulsive social media use and academic procrastination of undergraduate students of Nnamdi Azikiwe University.

Table 3: Simple correlation analysis of the relationship between compulsive social media use and academic achievement of undergraduate students

\begin{tabular}{lccc}
\hline$r$ & $r$ square & $r$ square adjusted & Std. Error of the Estimate \\
\hline 0.084 & 0.007 & 0.006 & 11.10160 \\
\hline
\end{tabular}


DEVELOPMENT

Vol. 10, No. 3, 2021, E-ISSN: 2226-6348 @ 2021 HRMARS

Data in Table 3shows that the correlation coefficient between social media addiction and academic achievement is $r=0.084$ with a coefficient of determination of 0.007 . This reveals that there is a low but positive relationship between social media addiction and academic achievement of undergraduate students of Nnamdi Azikiwe University.

Table 4: Simple correlation analysis of the relationship between gender and academic procrastination among undergraduate students

\begin{tabular}{lllll}
\hline Variable & Mean & SD & $r$ & Sig \\
\hline Gender & 1.50 & 0.50 & -0.012 & 0.353 \\
Academic Procrastination & 69.84 & 8.49 & & \\
\hline P $>0.05$ Not significant at 0.05 & &
\end{tabular}

$\mathrm{P}>0.05$ Not significant at 0.05

Data in Table 4 shows that gender has a mean of 1.50 and a standard deviation of 0.50 while academic achievement has a mean of 69.84 and a standard deviation of 8.49. The Table further revealed that the correlation coefficient between gender and academic achievement is $r=-0.012$. This implies that there is a low and negative relationship between gender and academic procrastination of undergraduate students of Nnamdi Azikiwe University. It further revealed that there is no significant relationship between gender and academic procrastination of the students

Table 5: Simple correlation analysis of the relationship between gender and academic achievement among undergraduate students

\begin{tabular}{lllll}
\hline Variable & Mean & SD & $r$ & Sig \\
\hline Gender & 1.50 & 0.50 & 0.038 & 0.119 \\
Academic Achievement & 54.55 & 5.66 & & \\
\hline P $>0.05$ Not significant at 0.05 & &
\end{tabular}

$\mathrm{P}>0.05$ Not significant at 0.05

Data in Table 5 shows that gender has a mean of 1.50 and a standard deviation of 0.50 while academic achievement has a mean of 54.55 and a standard deviation of 5.66. The Table further reveals that the correlation coefficient between gender and academic achievement is $r=0.038$. This shows that there is a low but positive relationship between gender and academic achievement of undergraduate students of Nnamdi Azikiwe University. It further reveals that there is no significant relationship between gender and the academic achievement of the students.

Table 6: Regression analysis of social media addiction and academic procrastination among undergraduate students

\begin{tabular}{lcccccccc}
\hline Source & SS & Df MS & $F$ & B & $\beta$ & $t$ & Sig & \\
\hline Regression & 63832.278 & 1 & 63832.278 & 11000.878 & 0.731 & 0.959 & 18.868 & .000 \\
Residual & 5587.780 & 963 & 5.802 & & & & & \\
Total & 69420.058 & 964 & & & & & & \\
\hline
\end{tabular}

Data in Table 6 show that an F-ratio of 11000.878 with an associated exact probability value of 0.00 was obtained. This exact probability value of 0.00 was less than 0.05 level of significance and therefore, found to be significant. Thus, the null hypothesis was rejected. The 
inference drawn was, therefore, that there was a significant relationship between social media addiction and academic procrastination among undergraduate students of Nnamdi Azikiwe University.

Table 7: Regression analysis of social media addiction and academic achievement of undergraduate students

\begin{tabular}{lcccccccc}
\hline Source & SS & Df & MS & F & B & $\beta$ & $t$ & Sig \\
\hline Regression & 846.060 & 1 & 846.060 & 6.865 & 0.166 & 0.05420 .722 & .000 \\
Residual & 5587.780 & 963 & 5.802 & & & & & \\
Total & 69420.058 & 964 & & & & & & \\
\hline
\end{tabular}

Data in Table 7 show that an F-ratio of 6.865 with an associated probability value of 0.09 was obtained. This probability value of 0.09 was greater than 0.05 level of significance and therefore, foundto be significant. Thus, the null hypothesis was not accepted. The inference drawn was, therefore, that there is a significant relationship between social media addiction and academic achievement among undergraduate students of Nnamdi Azikiwe University.

\section{Discussion}

The finding of the study revealed that $33.47 \%$ of the undergraduate students in NAU exhibit a high level of academic procrastination, $42.70 \%$ exhibit a moderate level of academic procrastination $23.83 \%$ exhibit academic procrastination among undergraduate students. This could be because a majority of the students have internet-friendly phones and they usually source information online.

The finding of the study revealed a high and positive relationship between social media addiction and academic procrastination among undergraduate students of Nnamdi Azikiwe University. When subjected to testing, the finding was also found to be statistically significant. The reason behind this could because of the present internet and social media era where lots of information is obtained from. Most students get carried away and distracted from properly using social media for academic purposes. The finding of this study corroborates with the existent findings that social media addiction has a positive relationship with academic procrastination (Nwosu et al., 2020; Hayat et al., 2020; Uztermur, 2020).

The finding of this study shows that social media addiction has a low but positive relationship with the academic achievement of undergraduate students of Nnamdi Azikiwe University. When tested further, it revealed a significant relationship between social media addiction and the academic achievement of the students. This could be because many of the students recourse to social media for getting information for their academic tasks. The finding of this study agrees with Albarashdi, 2020; Ipem and Okwara-Kalu (2020) that social media addiction has a positive relationship with the academic performance of undergraduate students. However, it disagrees with $\mathrm{Hou}$ et al (2019) who found a negative association between social addiction and academic performance of undergraduate students of Peking, University, China. This could be explained based on the distractions that some students experience with visiting the social media handles. This is why it is good to teach students proper time management and the need to set their priorities and academic goals and focus on them.

The finding of the study also shows that gender has low but a negative relationship with academic procrastination among undergraduate students. This is explainable because 
academic procrastination happens to every individual irrespective of gender. If one whether a male or a female student fails to set out academic goals with proper time management, the student can always fall prey to academic procrastination. The finding of this study corroborates with Mahasneh et al (2016); Ajayi (2020) found no significant difference in academic procrastination among male and female undergraduate students implying that gender has a negative relationship with academic procrastination. It further agrees with Gohil (2014) and Vij (2016) who found a significant difference in academic procrastination among male and female college students implying that gender has a positive relationship with academic procrastination. The reason for this difference in findings could be because of the time interval for the present study and that of Gohil and also Vij conducted in 2014 and 2016 respectively. If conducted now, Gohil and Vij might have a similar finding with this present study. Another reason could be the difference in the geographical location of the studies involved.

The finding of this study revealed that gender has a low but positive relationship with the academic achievement of undergraduates. It further revealed that the relationship was not significant. This could be explained because students' achievement is not dependent on their gender but their level of preparedness for their academic endeavours. This finding corroborates with some studies with secondary school students found that gender has no significant relationship with academic achievement (Anierobi, 2019; Odofin, 2020; Unachukwu et al., 2020). However, this finding disagrees with other researchers that gender has a significant relationship with the academic achievement of students (Baji, 2020; Mwihia, 2020; Sumaila \& Bello, 2018). This could be explained in line with the geographical locations of the studies which were mostly outside the country of the present study. Furthermore, the only study that was done in the same country but had a different finding was done three years ago which is enough time for a positive change in academic achievement to gender.

\section{Recommendation}

Based on the findings of this study, the researchers recommend as follows:

1. All stakeholders of education such as school authorities, parents and teachers should always channel the attention of students on the pros and cons of wrong use of social media which can distract their academic activities.

2. Schools should form a peer group association in schools where discussions on proper social media use should be encouraged.

3. Guidance counsellors should also play a good role in reorienting the students on the dangers of social media addiction to their academic life. Students should be taught how to manage their time properly and skills on how to set and pursue their academic goals with distractions from social media.

4. Teachers should keep students engaged through assignments and those that carried their out promptly should always be rewarded. This will challenge students to always pay attention to carrying out their academic tasks.

\section{Conclusion}

This study concluded that social media addiction is a significant factor in academic procrastination and academic achievement among undergraduate students of NnamdiAzikiwe University. The study further concludes that gender is not a significant factor in the academic achievement of students. 


\section{References}

Ahmed, U., Umrani, W. A., Pahi, M. H., \& Shah, S. M. M. (2017). Engaging PhD students: Investigating the role of supervisor support and psychological capital in a mediated model. Iranian Journal of Management Studies 10 (2), 283-306

Ajayi, O. S. (2020). Academic self-efficacy, gender and academic procrastination. Journal of Trans-disciplinary Studies 13(1). http://dx.doi.org/10.21533/epiphany/v13i1.324

Albarashdi, H. S. (2020). Social networking (SNS) addiction among university students: A literature review and research directions. Journal of Education, Society and Behavioural Science 33 (1), 11-33. https://doi.org/10.9734/jesbs/2020/v33i130191

Alrashidi, O., Phan, H. P., \& Ngu, B. H. (2016). Academic engagement: An overview of its definition, dimensions and major conceptualizations. International Educational Studies $9(12), 41-52$

Anierobi, E. I., Okeke, N. U., \& Etodike, C. E. (2021). Psychological Capital Components and Association of Students' Academic Achievement in Secondary Schools in Anambra State. Social Sciences and Education Research Review (8)1, 125 - 140. DOI: 10.5281/zenodo. 5090780

Anierobi, E. I., Etodike, C. E., Nwogbo, V. N., Okeke, N. U., \& Nwikpo, M. N. (2021). Evaluating Sexual Harassment against Female Workers in Higher Institutions in Anambra State, Nigeria. International Journal of Academic Research in Business and Social Sciences, 11(2), 265-278. http://dx.doi.org/10.6007/IJARBSS/v11-i2/8687 DOI:10.6007/IJARBSS/v11-i2/8687

Anierobi, E. I. (2020). Relationship among gender, academic self-concept and academic achievement of secondary school students in Awka Urban. The Educational Psychologist 13(1), 34-45.

Anierobi, E. I., \& Unachukwu, G. C. (2020).Achievement motivation and academic optimism as correlates of academic engagement among postgraduate students in Nnamdi Azikiwe University (NAU), Awka. Social Sciences and Education Research Review 1 (7), 242-263. www.sserr.ro

Baji, I. M. (2020).Analysis of gender differences in academic self-efficacy and achievement among secondary school students in Niger State, Nigeria. International Journal of Social Sciences 5(3), 155-164 .https://doi.org/10.20319/pijss.2020.53.659675

Balkins, M., \& Duru, E. (2017).Gender differences in the relationship between academic procrastination, satisfaction with academic life and academic performance. Electronic Journal of Research in Educational Psychology 15 (1), 105-125. http://dx.doi.org:10.14204/ejrep.41.16042

Chen, A. (2019). From attachment to addiction: The mediating role of need satisfaction on social networking sites. Computers in Human Behaviour 98, 80-92. https://doi.org/ 10.1016/j.chb.2019.03.034

Etodike, C. E., Ekeghalu, E. C., Ani, K. J., \& Mutambara, E. (2021). Covid-19 Fatality Rate in Third World Countries: A Review of Environmental Challenges and Impacts on Public Health and Human Security. Journal of Intellectual Disability - Diagnosis and Treatment, 2021, 9, 39-44 https://doi.org/10.6000/2292-2598.2021.09.01.5

Etodike, C. E., \& Ojiakor, I. C. (2018). Social Media Networks and associated vulnerability to sexual risk behaviours among adolescents. European Journal of Open Education and ELearning Studies 3(1), 66-78. http://www.oapub.or/edu DOI: 10.5281/zenodo.1252540 
DEVELOPMENT

Vol. 10, No. 3, 2021, E-ISSN: 2226-6348 ㄷ 2021 HRMARS

Etodike, C. E., Ike, P. R., \& Chukwura, E. N. (2017). Assertiveness Training: Academic Performance and Self-Esteem among College Students in Selected Rural Areas. International Journal for Psychotherapy in Africa 2(1), 7-13.

Etodike, C. E., Nwangwu, N. I., Nnaebue, C. I., \& Anierobi, E. I. (2020). Effect of Time Management and Monetary Rewards on Cognitive Task Accomplishment among Students of Nnamdi Azikiwe Secondary School, Awka, Nigeria. Canadian Social Science, 16 (8), 29-35. http://www.cscanada.net/index.php/css/article/view/11836 DOI: http://dx.doi.org /10.3968/11836

Gohil, E. (2014). Procrastination and self-esteem: A gender-based study. Global Journal of Interdisciplinary Social Sciences 3 (3), 91-95. https://www.longdom.org/articles/ procrastination -and-selfesteema-gender-based-study.pdf

Haand, R., \& Shuwang, Z. (2020). The relationship between social media addiction and depression: A quantitative study among university students in Khost, Afghanistan. International Journal of Adolescence and Youth 25 (1), 780-786. https://doi:.org/10.1080/ 02673843.2020.1741407

Hartney, E. (2019). An overview of behavioural addiction. Retrieved from https://presseinserm.fr/en.

Hayat, A. A., Kojuri, J., \& Amini, M. (2020). Academic procrastination of medical students: The role of internet addiction. Journal of Advances in Medical Education \& Professionalism 8(2), 83-89. doi:10.30476/JAMP.2020.85000.1159 https://www.ncbi.nlm.nih.gov/pmc /articles/PMC7188941/

$\mathrm{He}$, S. (2017). A multivariate investigation into academic procrastination of university students.Open Journal of Social Sciences 5, 12-24. https://doi:10.4236/jss.2017.51002

Hou, Y., Xiong, D., Jiang, T., Song, L., \& Wang, Q. (2019). Social media addiction: Its impact, mediation and intervention. Cyberpsychology: Journal of Psychosocial Research on Cyberspace 13 (1). http://dx.doi:.org/10.5817/CP2019-1-4

Ikwuka, O. I., Etodike, C. E., \& Okoli, O. K. (2020). Differential Effects of Instruction Technique and Gender on Secondary School Students' Achievement in Civic Education in Anambra State, Nigeria. Higher Education of Social Science, 19(1), 1-7. Available from: URL: http://www.cscanada.net/index.php/hess/article/view/11848

DOI:http://dx.doi.org/10.39 68/11848

Ipem, J. N., \& Okwara-Kalu, C. E. (2020). Internet addiction and academic performance of undergraduate students of Alvanlkoku Federal College of Education (AIFCE) Owerri. Journal of Nigerian Academy of Education 16 (2), 306-317.

Karima, S., Revenio, J., \& Van, D. (2017).Assessing the relationship between time management and academic performance of the Business Students in Al-Zahra College for women. European Business \& Management 3(1), 1-8.

https://doi:10.11648/j.ebm.20170301.11

Mahasneh, A. M., Bataineh, O. T., \& Al-Zoubi, Z. H. (2016).The relationship between academic procrastination and parenting style among Jordanian undergraduate students. The Open Psychology Journal 9, 25-34. https://openpsychologyjournal.com/VOLUME/9/PAGE/25/

McCloskey, J., \& Scieloz, S. A. (2015). Finally!: The development and validation of the academic procrastination scale. ResearchGate.

https://www.researchgate.net/publication /273259879 
Mwihia, C. (2020). Gender differences in academic achievement of students in Kinangop sub county, Nyandaruacounty, Kenya. European Journal of Social Sciences Studies 5(4), 4759.http://dx.doi.org/10.462827/ejsss.v5i4.863https://oapub.org/soc/index.php/EJSSS / article/view/863

Ndubuaku, V., Inim, V., Ndudi, U. C., Samuel, U. E., \& Prince, A. I. (2020). Effects of social networking addiction on academic performance ofuniversity students in Nigeria. International Journal of Recent Technology and Engineering 8(5), 173-180. https://doi: 10.35940/ijrte.D8393.018520

Nwosu, K. C., Ikwuka, O. I., Ugorji, M. O., \& Unachukwu, G. C. (2020). Does the association of social media use with problematic internet behaviours predict undergraduate students procrastination?.Canadian Journal of Learning and Technology 46 (1), 1-20. https://www.cjlt.ca/index.php/cjlt/article/view/27890/20481

Odofin, T. (2020). Influence of family socio-economic status on students' academic achievement in Delta central senatorial district, Delta State. Journal of the Nigerian Academy of Education, 16(1), 1-10.

Odofin, T., \& Ofojebe, E. N. (2020). Relationship between social media addiction and deviant behaviour among secondary school students in Delta State. Journal of Nigerian Academy of Education 16(2), 27-37.

Okeke, N. U., \& Anierobi, E. I. (2020).The influence of social media on aggressive behaviours of in-school adolescents in Anambra State. Journal of Nigerian Academy of Education 16 (1), 279-292.

Okeke, N. U., \& Joe-Akunne, C. O. (2020). Perceived influence of social media on adolescents aggressive behaviours in gender-specific schools in Anambra State. Journal of Nigerian Academy of Education 16 (2), 227-238.

Okoiye, O. E., \& Nlemadim, M. C. (2017). Impact of academic procrastination and study habits on expressed mathematics anxiety on junior secondary school students in Esan SouthEast, Edo State, Nigeria. British Journal of Psychology Research, 5 (1), 32-40 www.eajournals.org

Oriol, X., Amutio, A., Mendoza, M., Da-Costa, S., \& Miranda, R. (2016). Emotional creativity as predictor of intrinsic motivation and academic engagement of university students: The mediating role of positive emotions. Front Psychol 7

Rotgans, J. I., \& Schmidt, H. G. (2017). The Role of Interest in Learning: Knowledge Acquisition at the Intersection of Situational and Individual Interest. In The Science of Interest (pp. 69-93). Springer: Cham.

Sahin, C. (2018). Social media addiction scale- Student form: The reliability and validity study. The Turkish Online Journal of Educational Technology 17 (1), 169-182

Sandeep, L., Shouvik, C., Suparna, C., \& Avijit, H. (2019). Impact of social media on academic performance and inter-personal relation: A cross-sectional study among students oat a tertiary medical center in East India. Journal of Education and Health Promotion 8: 73. Https://doi:10.4103/jehp.jehp_365_18

Sumaila, M. U., \& Bello, M. U. (2018). Gender, interest and school type as predictors of academic achievement in trigonometryamong secondary school students in Kano State, Nigeria. ATBU Journal of Science, Technology and Education 6(4). https://www. atbuftejoste.com/index.php/joste/article/view/647

Tateno M., Kim, D. J., Teo, A. R., Skokaukas, N., Guerrero, A. P. S., \& Kato, T. A. (2019). Smartphone addiction in Japanese College students: usefulness of the Japanese version 
of the Smartphone Addiction Scale as a screening tool for a new form of internet addiction. Psychiatry Investig.16 (2). 115-120.

Tayo, S. S., Adebola, S. T., \& Yahya, D. O. (2019). Social media: Usage and influence $n$ undergraduate studies in Nigeria Universities. International Journal of Education and Development using Information and Communication Technology 15 (3), 53-62. https:// files.eric.ed.gov/fulltext/EJ1227664.pdf

Unachukwu, G. C., Anierobi, E. I., Nwosu, K. C., \& Okeke, N. U. (2020). Influence of academic self-efficacy and resilience on academic achievement among secondary school students in Aguata LGA, Anambra State, Nigeria. Journal of the Nigerian Academy of Education 16(2), 116-130.

Uztermur, S. (2020). The mediating role of academic procrastination behaviours in the relationship between pre-service social studies teacher's social media addiction and academic success. International Journal of Education Technology and Scientific Researches 5 (11), 63-101. https://doi:10.35826/ijetsar.112

Vij, J. (2016). Gender does not influence delaying excuses: An explanatory study of the reasons of academic procrastination among college students. The International Journal of Indian Psychology 3(3), 144-154. https://ijip.in/wpcontent/uploads/2019/02/18. 01.016.20160303.pdf

Yakut, E., \& Kuru, O. (2020). The role of social media usage purposes in the relationship between social media addiction and academic procrastination behaviour: A structural equation model study. Business and Management Studies: An International Journal 8 (2), 2193-2214. https://doi.org/10.15295/bmij.v8i2.1503 